\title{
To Open or Not to Open: Korean Rice Market
}

\author{
Youngjeen Cho \\ Graduate School of International Studies (GSIS), Ewha Womans University, Seoul, South Korea \\ Email: ycho@ewha.ac.kr
}

Received 24 September 2014; revised 21 October 2014; accepted 15 November 2014

Copyright (C) 2014 by author and Scientific Research Publishing Inc.

This work is licensed under the Creative Commons Attribution International License (CC BY). http://creativecommons.org/licenses/by/4.0/

(c) (i) Open Access

\begin{abstract}
Although the "tariff only" principle was adopted in the Uruguay Round (UR) negotiations on agricultural products, Korea was able to apply special treatment to its rice and postpone tariffication of rice imports. After two decades of delay, the Korean government officially announced its decision to open its rice market beginning in 2015 . This paper examines whether it would be legally possible for the Korean government to postpone the tariffication of rice imports beyond 2014. In order to address the question, this paper outlines the status of Korean rice in the WTO for the last twenty years. Then, it analyzes the arguments of those who are against tarifficating rice and of those who are in support of it. Based on the analysis, it concludes that Korea cannot postpone tariffication under Annex 5 of the Agreement on Agriculture. While it may request for a waiver under Article IX of the WTO Agreement, a careful and thorough examination is required to decide whether to postpone the tariffication beyond 2014.
\end{abstract}

\section{Keywords}

Korea, Rice, Tariffication, Special Treatment, Agreement on Agriculture

\section{Introduction}

On July 18, 2014, the Korean Minister for Agriculture ${ }^{1}$ officially announced the government's decision to open its rice market beginning in 2015. To be more exact, the Korean government decided to tarifficate rice imports. In the Uruguay Round ("UR") negotiations, participating countries agreed on the principle of "tariff only" or "tariffication without exception"” in terms of agricultural products. Therefore, WTO members were expected to convert non-tariff measures on agricultural products to tariffs, and reduce them gradually. Developed countries

\footnotetext{
${ }^{1}$ Formally, Minister for Agriculture, Food and Rural Affairs.

${ }^{2}$ Article 4, Agreement on Agriculture.
} 
were expected to reduce the tariffs by an average of 36 percent over 6 years during the implementation period, and developing countries were expected to reduce them by an average of 24 percent over 10 years. At the same time, the Agreement on Agriculture provides "special treatment" for particularly sensitive products so that imports can be restricted during the implementation period, i.e. by the end of 2000 for developed countries and by the end of 2004 for developing countries ${ }^{3}$. There are four countries that invoked the provisions: Korea, Japan, and the Philippines for rice, and Israel for sheep meat, whole milk powder and cheese. In addition, Chinese Taipei applied the special treatment to rice when it became a WTO member in 2002. Korea, who was acknowledged as a developing country at the UR negotiations, delayed tariffication of rice imports until the end of 2004, and extended the special treatment for an additional 10 years to the end of 2014. With its recent decision, the Korean government is to submit its draft Schedule reflecting the tariffication of rice, and if no objection is raised within 3 months, Certification of Modification and Rectifications will be issued to Korea, in accordance to the Decision on Procedures for Modification and Rectification of Schedule of Tariff Concession (GATT, 1980).

Korea might fall into political turmoil in the second half of this year, as there is unyielding opposition to opening its rice market to foreign products. On the day of the Agricultural Minister's announcement, farmers' groups gathered in front of the Government Complex and held over-night rallies, rebuking the government's decision to liberalize the rice market. Farmers' groups warned that they would hold a proclamation ceremony on September 1, which would be followed by a nationwide relay of demonstrations until the government overturned its decision ${ }^{4}$. Opponents uncompromisingly criticize the government for opening up its rice industry too soon and too easily, without taking any measure to protect it. They claim that the Korean government can keep its rice market closed either by extending the special treatment under the Agreement on Agriculture or by maintaining status quo until the Doha Development Agenda ("DDA") negotiations are complete.

Against this backdrop, this paper aims to examine whether it would be legally possible for the Korean government to postpone the tariffication of rice imports beyond 2014. In order to address the question, this paper outlines the status of Korean rice in the WTO for the last twenty years. Then, it analyzes the arguments of those who are against tarifficating rice and of those who are in support of it. While this paper's analysis tries to acknowledge the political and economic influence, its focus is on the legal analysis.

\section{Korean Rice in the WTO}

While Korea was able to postpone tariffication of rice imports as a result of the UR negotiations, such special treatment was subject to strict conditions. Korea was required to provide access to the rice market in the form of import quotas. This equated to importing 51,307 tons in 1995, as the minimum market access ("MMA") which was 1 percent of Korea's average annual rice consumption between 1988 and 1990. The required volume of the MMA increased incrementally to 205,228 tons in 2004, 4 percent of annual rice consumption ${ }^{5}$. In this context, it would be inappropriate, in a strict sense, to say that the Korean rice market has been closed, as Korea has been effectively importing foreign rice since 1995 although it was done in the form of quota and not on a tariff-basis.

On January 20, 2004, the Korean government announced its intention to initiate negotiations for the extension of the special treatment of rice, in accordance to Article 8 of Annex 5 of the Agreement on Agriculture (WTO, 2004). The Korean government conducted negotiations with the US, China, Australia, Thailand, India, Pakistan, Argentine, Egypt and Canada who had expressed interest in the Korean rice market. After eight months of negotiations with the nine countries, Korea reached agreements on substantive issues and submitted a draft revised Schedule to the WTO, and the revised Schedule was certified on April 13, 2005 (WTO, 2005), as no objection was raised within three months. The extension of the special treatment was conditional on the increase of the MMA from 4.4 percent to 7.96 percent of rice consumption ${ }^{6}$ in equal increments over the ten year period from 2005 to $2014^{7}$. The MMA volumes amounted to 225,575 tons in 2005 and 408,700 tons in $2014^{8}$. The MMA

\footnotetext{
${ }^{3}$ Annex 5, Agreement on Agriculture

${ }^{4}$ However, not all farmers' groups are in opposition to the government's decision. While the National Federation of Farmers' Association strongly criticizes government's decision to liberalize rice market, the Korean Advanced Farmers' Federation agrees to it, provided that government ensures enough protective measures.

${ }^{5}$ Art. 1, Section I-B: Tariff Quotas, Section I: Agricultural Products, Part I: Most-Favored-Nation Tariff, SCHEDULE LX—Republic of Korea.

${ }^{6}$ The base period for the consumption was 1988-1990.

${ }^{7}$ Art. 1, Section I-B: Tariff Quotas, Section I: Agricultural Products, Part I: Most-Favored-Nation Tariff, SCHEDULE LX—Republic of Korea.

${ }^{8} I d$.
} 
volume in 2004, i.e. 205,228 tons, was allocated to China, the US, Thailand and Australia as Country-SpecificQuotas (CSQs) on the basis of the historical trade flows from 2001 to 2003, and the allocated volume to the four countries was 116,159 tones, 50,076 tons, 29,963 tons and 9030 tons, respectively ${ }^{9}$. Furthermore, Korea agreed to increase imports of table rice $1^{10}$ from no less than 10 percent to no less than 30 percent of the total MMA volume, in equal increments over six years from 2005 to $2010^{11}$. In addition to the multilateral agreements reached, there were bilateral agreements between Korea and each of the other nine countries, with the exception of Pakistan, on technical and procedural issues involving the implementation of the multilateral agreements as well as on certain supplementary issues. Adjustment tariffs on fishery products, risk assessment procedures for beef, poultry, and fruits, etc. are known to be contained in the bilateral supplementary agreements (Korean Ministry of Agriculture and Forestry, 2005), although the exact contents are undisclosed. Article 9 of Annex 5 to the Agreement on Agriculture provides that WTO members who want to extend the application of the special treatment shall "confer additional and acceptable concessions as determined in that negotiation". "The concessions can be made through bilateral agreements as well as multilateral agreements as long as it is the outcome of the negotiations.

\section{Further Extension of Special Treatment?}

Those who claim that the Korean government can keep its rice market closed further argue that this can be done under Annex 5 of the Agreement on Agriculture. Firstly, it is argued that Articles 3 and 4 of Annex 5 permit Korea to negotiate with WTO members to extend the special treatment on its rice (Lee, 2014). As mentioned above, the "tariff only" principle was adopted as a result of the UR negotiations in terms of agricultural products, and Article 4 stipulates such principle. At the same time, Article 4.2 provides for exceptional treatments, which are elaborated in Annex $5^{12}$. Articles 3 and 4 of Annex 5 provide:

3. Any negotiation on the question of whether there can be a continuation of the special treatment as set out in paragraph 1 after the end of the implementation period shall be completed within the time-frame of the implementation period itself as a part of the negotiations set out in Article 20 of this Agreement, taking into account the factors of non-trade concerns.

4. If it is agreed as a result of the negotiation referred to in paragraph 3 that a Member may continue to apply the special treatment, such Member shall confer additional and acceptable concessions as determined in that negotiation.

Article 3 stipulates that a member may initiate a negotiation within a certain time frame, and Article 4 states that the special treatment can be continued provided that an agreement is reached as a result of the negotiation. However, these provisions are not applicable to the Korean rice case. These articles fall under Section A of Annex 5 , which is originally designed to apply to special treatment for certain agricultural products designated by developed countries. Therefore, Japan and Israel postponed tariffication of their rice, sheep meat and certain dairy products under Section A. At the same time, special treatment for rice of Korea and the Philippines were permitted not by invoking the articles of Section A, but instead, those of Section B. And thus, Korea cannot resort to these articles to extend the postponement of tariffication, as they were not initially used to grant such treatment. In addition, even if Korea were able to cite Article 3, it cannot extend the special treatment because of the time frame provided in the provision, which is further explained below.

It is also argued that Korea can adopt a standstill position and not tarifficate rice while maintaining the current MMA on the basis of Article 3. Some commentators claim that "a negotiation set out in Article 20" provided in Article 3 means the DDA negotiations, and point to the fact that many countries are taking standstill positions at the DDA (Opening Rice Market, 2014). Article 3 refers to Article 20 for the meaning of "a negotiation", which Article 20 provides that "Members agree that negotiations for continuing the process will be initiated one year before the end of the implementation period". This is a "built-in agenda" of the Agreement on Agriculture. Un-

\footnotetext{
${ }^{9}$ Art. 3.1, Section I-B: Tariff Quotas, Section I: Agricultural Products, Part I: Most-Favored-Nation Tariff, SCHEDULE LX—Republic of Korea.

${ }^{10}$ Table rice refers to rice distributed into the Korean market for table use and not for the preparation of baker's wares or other foods.

${ }^{11}$ Art. 6.2, Section I-B: Tariff Quotas, Section I: Agricultural Products, Part I: Most-Favored-Nation Tariff, SCHEDULE LX—Republic of Korea.

${ }^{12}$ Article 4.2 provides that "Members shall not maintain, resort to, or revert to any measures of the kind which have been required to be converted into ordinary customs duties, except as otherwise provided for in Article 5 and Annex 5.”
} 
der Article 20, WTO members were expected to initiate a negotiation to continue the reform process by the end of 1999, i.e. a year before the end of the implementation period, as explained below. The negotiations began in 2000 and when the WTO members agreed to launch the DDA negotiations at the Ministerial Conference held in Doha in 2001, the agriculture negotiation became a part of it. Although "a negotiation" was not envisioned to mean the DDA negotiations, it could be interpreted as that, as the negotiations mandated by Article 20 have merged into the DDA. In practice, however, this issue is moot and has not been disputed before the WTO panels or the Appellate Body, because Japan and Israel, who are eligible for Article 8, no longer apply the special treatment, and there is no merit for them to challenge it. As aforementioned, Article 3 does not apply to the Korean case, and Korea's negotiation on the extension of the special treatment is not a part of the DDA. In fact, Korea's obligation to tarifficate its rice imports once the special treatment expires is the result of the UR negotiations that preceded the DDA. Furthermore, maintaining a "standstill" is not a strategy that can be used in a manner that is suggested by some commentators. Although there is no clear definition of this concept, it is conventionally used it two ways in the context of the WTO. Firstly, WTO members are expected not to regress in a direction that goes against trade liberalization even in the vacuum of relevant rules. It other words, WTO members should "standstill" and not retrogress. Secondly, in the DDA talks, members are not required to implement what they have agreed until everything is agreed. WTO members adopted a single undertaking rule in the DDA, under which, "Nothing is agreed until everything is agreed". Therefore, although members reached agreements on certain issues, such agreements are provisional, in a strict sense, and members need not implement them until they agree on the whole package of the negotiations, which is commonly used as a strategy to strengthen members' leverage in the negotiations (Choi, 2014). Overall, neither concept of "standstill" can justify Korea's position if it chooses not to tarifficate rice imports without taking any other action.

Secondly, in addition to Articles 3 and 4, commentators also resort to Articles 8 and 9 of Annex 5 in deploying their argument that Korea can negotiate with WTO members to continue special treatment on its rice (Government Can Postpone the Tariffication of Rice, 2014). These articles provide:

8. Any negotiation on the question of whether there can be a continuation of the special treatment as set out in paragraph 7 after the end of the 10th year following the beginning of the implementation period shall be initiated and completed within the time-frame of the 10th year itself following the beginning of the implementation period.

9. If it is agreed as a result of the negotiation referred to in paragraph 8 that a Member may continue to apply the special treatment, such Member shall confer additional and acceptable concessions as determined in that negotiation.

In principle, these provisions can be applied to the Korean rice case as long as it meets the specified criteria. Articles 8 and 9 fall under Section B, and Article 7 explicitly says it applies to "a primary agricultural product that is the predominant staple in the traditional diet of a developing country Member", which is rice in Korea and the Philippines. Korea and the Philippines, who were acknowledged as developing countries, were initially allowed to keep their rice from tariffication in accordance to Article 7. Then, would it be possible for Korea to invoke Articles 8 and 9 in 2014 to initiate a negotiation to delay the tariffication of rice imports? The answer is negative. Article 8 explicitly provides a time frame for the initiation of the negotiation as "within the $10^{\text {th }}$ year itself following the beginning of the implementation period". Korea initiated the negotiation in 2004, i.e. the $10^{\text {th }}$ year following the beginning of the implementation period in accordance to Article 8. It is argued that Korea can resort to this provision again as the year of 2014 is the $10^{\text {th }}$ year following the beginning of the implementation period (Government Can Postpone the Tariffication of Rice, 2014). This argument seems to interpret "the implementation period" as the period implementing the special treatment. Within this interpretation, since the extension of the special treatment began in 2005 , the $10^{\text {th }}$ year following it would be 2014. This interpretation seems to be based on the assumption that a member can extend the special treatment repeatedly under Article 8, provided that an agreement is reached through the negotiation. However, the structure of the Agreement on Agriculture does not allow such interpretation. Article 4 declares the principle of tariffication, and the only exception is allowed by Annex 5, which was invoked by four member countries. When there is a principle and an exception, it would be rational to interpret the exception as narrowly as possible; otherwise exceptions might trump the principle. Moreover, Article 1 explicitly defines the term "implementation period" as "the six-year period commencing in the year 1995" "unless the context otherwise requires". Although Article 15.2 provides that "Developing country Members shall have the flexibility to implement reduction commitments over a period of 
up to 10 years”, the year 1995 is the commencing year of the period. And thus, as this definition applies to Article 9 of Annex 5, "the beginning of the implementation period" should be interpreted as the year 1995 and not the year 2005. It might be argued that the context of Article 8 supersedes the definition provided by Article 1 (f), based on the phrase "unless the context otherwise requires" in Article 1, and "implementation period" could be interpreted as "period implementing special treatment" and not as defined in Article 1 (f). However, it hardly seems that the context of Article 8 supports such departure. As mentioned above, Article 8 delineates the exception from the principle. Therefore, it would be highly inappropriate to justify the desertion from the original definition in order to widen the scope of exception. Therefore, it is not legally possible for Korea to extend the special treatment on its rice in accordance to either Article 3 and 4 or Articles 8 and 9.

Consequently, does it mean that it is completely impossible for Korea to negotiate with other WTO Members to delay the tariffication? The answer is no. Firstly, Korea can invoke Article IX of the Agreement Establishing the World Trade Organization (WTO Agreement), and request a waiver. Article IX provides:

3. In exceptional circumstances, the Ministerial Conference may decide to waive an obligation imposed on a Member by this Agreement or any of the Multilateral Trade Agreements, provided that any such decision shall be taken by three fourths of the Members unless otherwise provided for in this paragraph.

Korea may request to waive its obligation to tarifficate rice imports. Such request would be submitted to the Council for Trade in Goods for consideration, and within 90 days from the submission, the Council shall submit a report to the Ministerial Conference ${ }^{13}$. In fact, the Philippines applied for such a waiver. In 2006, the Philippines extended the special treatment on its rice for seven years till June 2012. As expiration approached, the Philippines expressed its intention to further extend the special treatment, and began negotiations with interested Members. It filed the first request for waiver to the Council for Trade in Goods in March 20, 2012 (WTO, 2012), but in vain. After more than two years of negotiations with interested members, the Philippines finally concluded bilateral agreements and submitted the request to the Council for Trade in Goods (WTO, 2014). It was approved there on June 19, 2014, and the decision of the Council for Trade in Goods was adopted by the General Council on June 24, 2014. While the Philippines has been given a five-year waiver from July 2012 to June 2017 for its rice market, it is based on strict conditions yet again. The Philippines should expand its MMA for rice by 2.3 times from 350,000 tons to 805,000 tons, and its CSQs from 138,000 tons allocated to three countries to 750,000 tons to seven countries (WTO, 2014). In addition, it is conjectured that the US, Canada, Thailand, etc. were ensured more access to its beef and poultry market, although the exact content is undisclosed. Korea might be able to acquire a waiver on special treatment for rice by invoking Article IX. However, even if it succeeded, it would require additional concessions. To be exact, it would be impossible for Korea to get such waiver without expanding its MMA and providing additional benefits to interested members. In order to obtain the waiver, it is obvious that Korea would be expected to pay far more than it did in 2005, as can be seen in the Philippines' example. In 2005, the Korean government faced bitter reproaches from farmers' groups for paying what they considered to be an excessive amount to postpone the tariffication of rice.

Secondly, Korea can try to acquire special treatment through the DDA negotiations. In fact, there is no limitation on issues that can be raised in the DDA negotiations. However, again, this is a negotiation, of which the most characteristic nature is give-and-take. In addition, the DDA talks have been paralyzed since it deadlocked in April 2011. And, unfortunately, it is doubtful whether WTO members have enough will to revive it.

The remaining question is: should Korea acquire the waiver to extend the special treatment by paying a quid pro quo in order to protect its rice market? It should to be examined carefully whether the waiver can actually protect the Korean rice market from foreign rice as it is asserted, or if it is simply a myth. In order to address the question, it is helpful to examine the examples of Japan and Chinese Taipei ${ }^{14}$. Japan ceased to apply the special treatment before its expiration, and Chinese Taipei chose not to extend it after a one year-period. As a result, both members transferred to tariffication of rice imports, in April 1999 and January 2003, respectively. The MMA volume of Japan and Chinese Taipei were fixed at 7.2 percent and 8 percent of annual rice consumption, which amounted to 767,000 tons and 144,720 tons, respectively ${ }^{15}$. In 2012, more than a decade after the tariffication, Japan imported 7.3 percent of annual rice consumption, while Korea imported 7.5 percent (Kim, 2014).

\footnotetext{
${ }^{13}$ Article IX:3(b) of the WTO Agreement.

${ }^{14}$ Chinese Taipei is a Member of the WTO under the formal name of Separate Customs Territory of Taiwan, Penghu, Kinmen and Matsu.

${ }^{15}$ Article 1 of Annex 5 sets the MMA volume of Japan in the first year of the implementation period as 4 percent of domestic consumption, and provides that it would be increased by 0.8 percent annually. Moreover, Article 2 provides that once Japan ceases to apply the special treatment, the MMA volume should increase by 0.4 percent for the remainder of the implementation period.
} 
While the MMA of Japan has remained stable at the rate of 7.2 percent since 2000, Korea's MMA has increased every year. In 2013, Japan imported only 504 tons of rice in addition to its MMA volume (Kim, 2014). The numbers show that tariffication per se does not necessarily lead to the surge of imported rice as feared by some people. If the Korean government decided to extend the special treatment in 2005 with a goal to minimize rice imports, it should be questioned whether the goal has been achieved.

Moreover, it is anticipated that Korea would need to expand its annual MMA volume to at least twice the current level which amounts to 800,000 tons in order to gain the waiver. This is a serious problem, especially considering that Korea's annual rice consumption per capita has gradually decreased over the last several decades, declining from 136.4 kilograms in 1970 to 82 kilograms in 2004. Korea's MMA volume in 2014, which was set at 7.96 percent of average annual rice consumption between 1989 and 1990, amounts to 9 percent on the basis of rice consumption in 2013. This is why many people, including certain farmers groups, support tariffication, not only because it is Korea's obligation as a WTO member, but also it is a better tool to minimize rice imports. Experts assess it is appropriate to set the tariff rate around 200 - 400 percent (Delay of Rice Tariffication, 2014; No Need for Further Negotiations? 2014). The government also said that, with a tariff higher than 300 percent, Korean rice can maintain its competitiveness in the Korean market and there would not be a sudden increase of imports (Keep a High Tariff on Rice, 2014). While some experts argue that a 400 percent tariff should be secured to protect the Korean rice market, others say 200 percent would be enough as the gap between the domestic price and the world market price has narrowed. In fact, in 2005, Korean rice costs around four to five times the world market price, and, in 2013, it became two to three times of the world market price, as the latter has gradually increased.

Overall, keeping the Korean rice market from tariffication by acquiring the waiver with strict conditions does not seem to be an efficient or effective way to maintain the competitiveness of Korean rice.

\section{Conclusion}

After postponing the tariffication of rice imports for twenty years, the Korean government decided to liberalize its rice market in 2015. When the government officially announced the decision, it was criticized for giving up its rice industry, rather than taking advantage of measures to continue protecting it. The opponents claim that the Korean government can delay the tariffication either by extending the special treatment under the Agreement on Agriculture or by maintaining status quo until the Doha Development Agenda (DDA) negotiations are complete. However, Korea can neither cite Annex 5 of the Agreement on Agriculture nor adopt a standstill position under the DDA in order to extend the special treatment of its rice. While Korea can request a waiver in accordance with the WTO Agreement or to bring the issue to the DDA, it is highly questionable whether this action would enable Korea to achieve its goal of minimizing rice imports. Although Korea may be able to acquire the waiver, it would be required to engage in a quid pro quo such as substantially expanding its MMA volume and other commitments in bilateral agreements. Therefore, tariffication is a better system for Korea to maintain the competitiveness of its rice in the domestic market.

\section{References}

Choi, W. (2014). Opening Korean Rice Market—It Cannot Be Postponed Again. Chosun Il-bo. http://news.chosun.com/site/data/html_dir/2014/02/18/2014021804770.html

Delay of Rice Tariffication Works against the Farmers as well as the Government (2014). Herald Economy. http://news.heraldcorp.com/view.php?ud=20140305000319\&md=20140308005344_BK

GATT (1980). Procedure for Modification and Rectification of Schedule of Tariff Concessions: Decision of 28 March 1980 , L/4962, 28 March 1980.

Government Can Postpone the Tariffication of Rice Imports (2014). Voice of People. http://www.vop.co.kr/A00000770919.html

Keep a High Tariff on Rice (2014). Seoul Shin-Moon. http://seoul.co.kr/news/newsView.php?id=20140719001014

Kim, Y. (2014). Rice Is Already Being Imported. JoongAng Il-bo. http://article.joins.com/news/article/article.asp?total_id=15157239\&cloc=olink|article|default

Korean Ministry of Agriculture and Forestry (2005). Outcomes of the Rice Negotiations and Future Plan: Report to the Agriculture, Forestry, Oceans and Fisheries Committee of the National Assembly, 253 ${ }^{\text {rd }}$ Session on April 18, 2005. http://seoul.co.kr/news/newsView.php?id=20140719001014

Lee, H. (2014). Opening of the Rice Market: It Is Not an Obligation under International Law. Chosun Il-bo. 
http://news.chosun.com/site/data/html_dir/2014/03/02/2014030202447.html

Opening Rice Market: Gain or Loss? (2014). Segye Il-bo. http://www.segye.com/content/html/2014/03/03/20140303005324.html?OutUrl=naver

WTO (2004). Notification of Initiating the Negotiations Set out in Section B of Annex 5 of the Agreement on AgricultureCommunication from Korea, G/AG/W/62, G/L/668, 20 January 2004.

WTO (2005). Certification of Modifications and Rectifications to SCHDULE LX-Republic of Korea, WT/Let/492, 13 April 2005.

WTO (2012). Request for Waiver on Special Treatment for Rice of the Philippines, G/C/W/665, 20 March 2012.

WTO (2014). Request for Waiver on Special Treatment for Rice of the Philippines, G/C/W/665/Rev.4, 27 March 2014. 
Scientific Research Publishing (SCIRP) is one of the largest Open Access journal publishers. It is currently publishing more than 200 open access, online, peer-reviewed journals covering a wide range of academic disciplines. SCIRP serves the worldwide academic communities and contributes to the progress and application of science with its publication.

Other selected journals from SCIRP are listed as below. Submit your manuscript to us via either submit@scirp.org or Online Submission Portal.
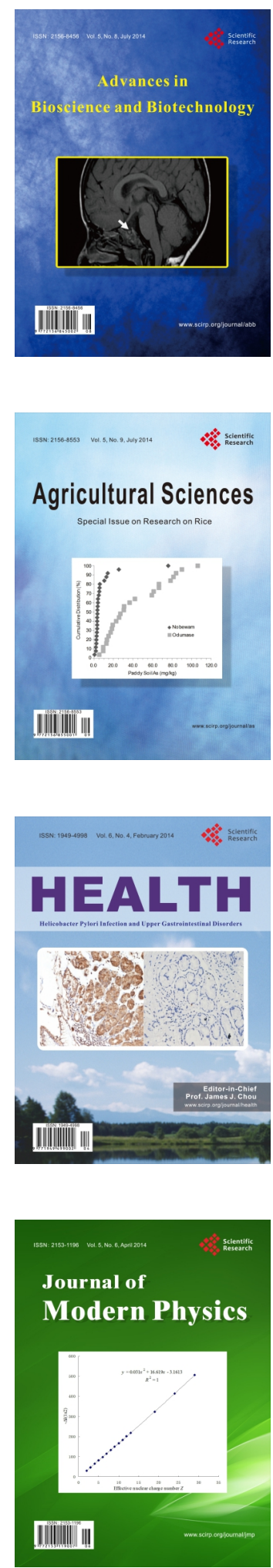
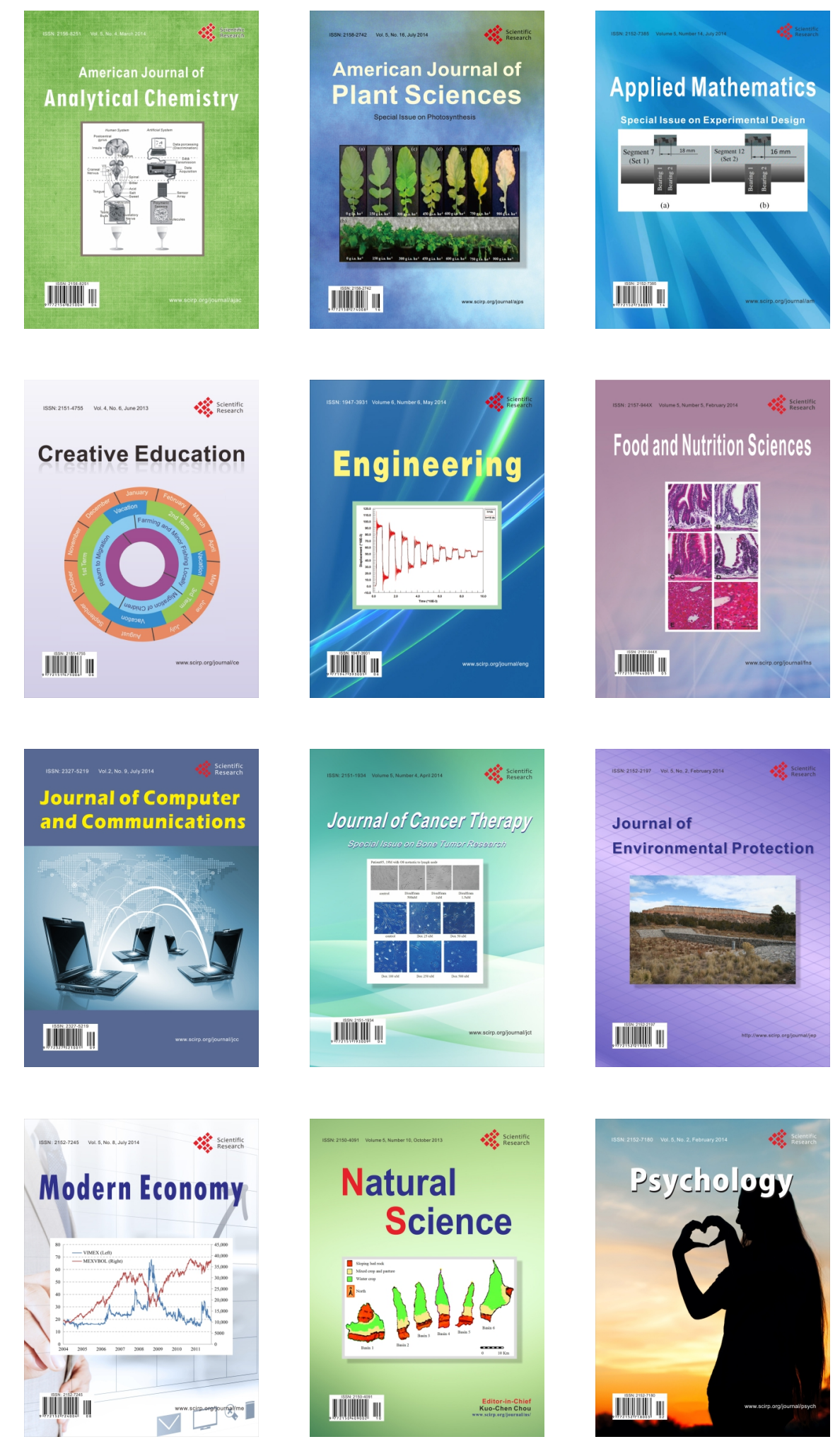